811.163.41'374'373.45

https://doi.org/10.18485/sj.2021.26.1.27

СЛОБОДАН Б. НОВОКМЕТ*

Институт за српски језик САНУ

Београд

\section{МАРИЈАНА Р. ЂУКИЋ}

Институт за српски језик САНУ

Београд
Оригинални научни рад

Примљен: 13. 10. 2020.

Прихваћен: 12. 1. 2021.

\title{
ЛЕКСИКОГРАФСКА АНАЛИЗА РЕЧНИКА СТРАНИХ РЕЧИ, КОJЕ СЕ ЈАВЉАЈУ У НАС ТЕ ИХ ВАЉА РАЗУМЕТИ, А ПОНЕШТО ИХ СЕ И КЛОНИТИ ЈОВАНА ГРЧИЋА ИЗ 1904. ГОДИНЕ
}

Наш рад бави се лексикографском анализом Речника страних речи, које се јављају у нас те их ваља разумети, а понешто их се и клонити Јована Грчића из 1904. године. Основни фокус рада је на сагледавању концепције речника, то јест, на анализи његове макро и микро структуре и лексикографских техника коришћених у његовој изради. Циљ рада јесте да се на примеру једног од наших првих речника страних речи општег типа утврде методолошки поступци при обради страних речи карактеристични за српску лексикографију с почетка 20. века и да се евентуално укаже на њихове недостатке у односу на приступ обради страних речи у савременој лексикографији.

Кључне речи: српски језик, Речник страних речи, Јован Грчић, лексикографија, макроструктура речника, микроструктура речника.

*slobodan.novokmet@isj.sanu.ac.rs

** Рад је настао као резултат финансирања Министарства просвете, науке и технолошког развоја Републике Србије према Уговору број 451-03-9/2021-14. 


\section{1. УВОДНЕ НАПОМЕНЕ}

\section{1. Предмет, задатак и циљ истраживања}

1.1.1. Предмет истраживања овог рада јесте један од првих штампаних речника страних речи у српском језику - дело илустративног наслова - Речник страних речи, које се јављају у нас те их ваља разумети, а понешто их се и клонити, ${ }^{1}$ аутора Јована Грчића. Овај речник специфичан је и по томе што је један од најстаријих штампаних речника општег типа, што значи да обухвата лексику страног порекла у целости, без селекције у избору презентованог корпуса према терминолошким, територијалним, временским и др. критеријумима. $^{2}$ Задатак истраживања јесте сагледавање концепције поменутог речника, тј. анализа његове макроструктуре и микроструктуре. Општи циљ истраживања јесте да се преко анализе макроструктуре и микроструктуре једног старијег лексикографског дела ${ }^{3}$ утврде методолошки поступци при обради страних речи карактеристични за српску лексикографију са почетка 20. века.

\section{2. Опште напомене о Речнику страних речи Јована Грчића}

1.2.1. Речници страних речи садрже лексику страног порекла која је у српски језик улазила у различитим периодима његовог развоја (Оташевић 2018: 277). Они представљају посебан тип речника, будући да садрже елементе енциклопедизма, који доприносе јаснијем и тачнијем објашњењу семантике и бољем разумевању етимологије речи, те самим тим кориснику нуде знатно шира знања о језику и свету који га окружује (исп. Магомедгажиева 2010: 114). Према подацима коју су нам досад познати из литературе, наш најстарији штампани речник страних речи општег типа објављен је 1875 . године у Панчеву и носи назив Речник страних речи, које се употребљавају у говору, у новинама, у повременим списима и у књигама, објашњен онима који те речи не разуму (Спасић 1996: 99; Оташевић 2018: 279). По хронологији објављивања,

${ }^{1}$ Речник страних речи, које се јављају у нас те их ваља разумети, а понешто их се и клонити, у Новом Саду, издање и штампа Браће М. Поповића 1904. године. У наставку рада употребљаваћемо назив - Речник страних речи.

${ }^{2}$ Наиме, насупрот речницима страних речи општег типа, постоје и специјализовани речници, који обухватају страну лексику из једног или више сродних језика или стране речи из одређеног дела српске језичке територије, потом терминолошки речници страних речи и сл. Наведена подела речника страних речи, као и њихов приказ, из хронолошке перспективе, представљени су у Оташевић 2018: 277-289.

${ }^{3}$ Приликом проучавања историјских лексикографских дела „узима се у обзир њихова макроструктура (нпр. избор лексичке грађе у историјском речнику, који даје хоризонтални пресек лексичког фонда у одређеном периоду друштвеног развитка), као и микроструктура (нпр. законитости обраде одредница у историјском речнику, које одсликавају формално-научне принципе у обради језичког материјала који су заслужни за организацију речника као лингвистичког дела)" (Ивановић 2017: 77-78). 
следећи штампани општи речник страних речи јесте Речник страних речи Јована Грчића, ${ }^{4}$ чије је прво издање, које је и предмет наше анализе, изашло 1904. године. Речник је доживео још два издања, 1913. и 1922. године.

1.2.2. О речницима страних речи у српском књижевном језику с почетка 20. века, али и о самом Грчићевом речнику, налазимо податке у прилогу Миливоја Павловића (Павловић 1928). Основни проблем речника страних речи из тог периода аутор види у корпусу стране лексичке грађе коју обухватају, будући да ти речници не осликавају реалну језичку ситуацију, односно не раде се према „потребама нашег народа”, већ доносе многе стране речи којих „уопште нема у употреби” (Павловић 1928: 218).

О речнику Ј. Грчића писао је и Веселин Ђисаловић, наводећи да се у друштву осећа потреба за оваквим речником „који би нас упућивао, како да се клонимо т. зв. варваризама, т. ј. туђинских речи и туђинског склопа српских речи" (Ђисаловић 1905: 95). Иако истиче различите недостатке Грчићевог речника - почев од терминолошких области које су слабо заступљене, преко погрешних или непрецизних тумачења семантике и етимологије речи, до начина транскрипције - оцена му је позитивна, па свој приказ речника завршава речима: „иначе се мора признати, да је [књига] лепу грађу обухватила, да јасно и кратко тумачи стране речи, да је српски језик леп и правилан, да је далеко надмашила све досадашње наше речнике страних речи [...] те свака боља кућа српска треба да је набави” (Ђисаловић 1905: 101).

\section{2. МАКРОСТРУКТУРА РЕЧНИКА СТРАНИХ РЕЧИ JОВАНА ГРЧИЋА}

2.0. Питања макроструктуре једног речника тичу се корпуса који је предмет лексикографске дескрипције (типови лексичке грађе), принципа презентације лексичке грађе и броја лексичких уноса, као и присуства/одсуства одређених пратећих елемената у речнику који су у функцији предусретљивости према кориснику (предговор у којем се дају основни подаци о речнику, упутства за коришћење речника, списак извора, попис скраћеница и сл.) (исп. Шипка

${ }^{4}$ Јован Грчић (1855-1941) био је српски књижевник, књижевни, позоришни и музички критичар, преводилац и професор Српске велике православне гимназије у Новом Саду. Предавао је српски, латински, грчки, немачки и мађарски језик са књижевношћу. Свестран културни радник који је већи део професионалног живота посветио образовном систему, Грчић је објавио и историју старогрчке, римске и српске књижевности, хрестоматије, драмска дела и њихове преводе. Његов лексикографски рад укључује и Речник српског и мађарског језика, I-II (Нови Сад, 1902) и Српско-немачки и немачко-српски речник, I-II (Нови Сад, 1905) (в. https://www.snp.org. rs/enciklopedija/?p=4400, приступљено 28. 8. 2020). 
2006: 164-166). ${ }^{5}$ Одабир грађе и начин индексирања селектованог материјала главни су елементи макроструктуре једног речника (Хартман 2005: 196). У наредним редовима представљени су подаци до којих се дошло анализом макроструктуре Речника страних речи Јована Грчића из 1904. године.

\section{1. Обим речника и начин презентације лексичке грађе}

2.1.1. Речник има 399 страна двостубачног текста и садржи око 7.105 појмова са статусом одреднице. Статус одреднице имају и вишечлане лексичке јединице - страни изрази, пословице, афоризми, сентенце, цитати и сл. (најчешће забележени изворном графијом, уз напомену о изговору). Број укупних лексичких уноса је, међутим, знатно већи, будући да је у речнику обрада грађе извршена по семантичко-деривационом моделу, односно по систему породице речи. Овај систем подразумева да се под одредницом наводе и лексикографски обрађују и остале речи са истим кореном. Такође, уколико се дата одредница остварује и као компонента одређених израза, ти се изрази наводе након значења одреднице. Тако се на пример под одредницом $\bar{u} и к$ 'срдња, љутиња, потајна мржња' наводи израз имайи йик на кога 'мрзити, гонити, узети на зуб'.

2.1.2. Одреднице су евидентиране према азбучном редоследу и навођене су, по правилу, транскрибовано, ћириличким писмом (понекад је у загради наведен и изворни, латинички облик речи), док су у латиничкој графији дати углавном изворни, неадаптирани изрази, махом латинског порекла (који су у речнику, иначе, регистровани у великом броју). Одреднице у овом издању нису акцентоване.

\section{2. Типови лексичке грађе}

2.2.1. Речник страних речи Јована Грчића представља богату ризницу позајмљеница из готово свих језика који су у прошлости утицали како на српски народни, тако и на књижевни језик. Бројчано су најзаступљеније позајмљенице из грчког и латинског, затим из француског, немачког и турског језика. ${ }^{6}$

${ }^{5}$ Љиљана Спасић (1996: 98) побраја сегменте макро и микро структуре речника ове врсте: „У речницима страних речи могу се пратити следећи лексикографски параметри: да ли имају предговор и шта он садржи, постоје ли подаци о обиму речника, о лексичком корпусу, има ли одредница морфолошких ознака, да ли се под одредницом наводе и изведенице и групе семантички повезаних термина, јесу ли речи акцентоване, има ли примера, спомиње ли се број језика из којих су речи преузете и који су то језици, као и то да ли се речи наводе и у изворном облику, да ли је заступљен фонетски принцип у писању, затим да ли се спомињу извори који су коришћени при изради речника, има ли попис скраћеница, да ли је речник штампан ћирилицом или латиницом, да ли је азбучни или абецедни, број страна, формат и др.”

${ }^{6}$ Јелена Јовановић (2006: 235) наводи народне пословице из Вукове збирке које на занимљив начин откривају са којим се све страним језицима наш човек у прошлости по неопход- 
Основна карактеристика корпуса Грчићевог речника јесте несагласност са општим правилом шта све треба, а шта не треба да уђе у један речник страних речи намењен општој употреби код широког круга корисника, различитог нивоа образовања. ${ }^{7}$ Наиме, у анализираном речнику налазе се различити типови лексичке грађе, међу којом је много оних јединица које припадају специјализованим речницима страних речи, енциклопедијама и лексиконима.

Поред одомаћених страних речи и израза који припадају општем лексичком фонду, као и терминолошким системима, Речник страних речи Ј. Грчића садржи и: ${ }^{8}$

a) изворне пословице, изреке, сентенце, цитате и сл. (non omnes omnia possunt 'не могу сви све'; divide et impera 'растави па владај!'; qui s'excuse, s'accuse 'ко се правда, оптужује се са̂м'; God save the king или queеn 'да Бог поживи краља или краљицу! (стара енглеска имена)'; de gustibus non est disputandum 'о укусима не ваља препирати се'; voi ch'entarte, lasciate ogni speranza 'ви, који улазите, не надајте се више ничему (Дантеов Пакао III) итд.);

б) изразе терминолошког карактера (углавном наведене у изворном облику, а ретко транскрибовано), најчешће из области правосуђа или шире - „правног језика" (jus devolutionis 'право, по којем по мужевљевој или жениној смрти све имање пређе на децу а жена и муж добије само ужитак'; luat in corpore, qui non habet in aere 'нека плати или откија телом (затвором или шибама), ко не може новцем', бил оф диворс (bill of divorce) 'тужба на развод' итд.);

в) различите врсте скраћеница (a.m. $c$. = a mundo condito 'од како је свет створен'; ex cons. (скр. ex consensu) 'по пристанку или погодби'; e. p. = en personne 'сам главом (на посетницама'; div. 'скр. на рецептима за divide = подели или dividatur = нек се подели'; v. D. = volente Deo 'ако хоће Бог, ако да̂ Бог’ итд.);

г) богат регистар антропонима: имена из религије, књижевности, митологије, историје, уметности итд. (Адам, Авељ, Бах, Волтер, Отело, Санчо Панза, Харпагон, Темида, Пенелопа, Сизиф, Гарибалди, Маријот, Платон итд.);

ности сучељавао и како их је доживљавао. С тим у вези, ауторка констатује: „Изгледа да му је турски био неразумљив и несимпатичан, и поред тога што је с њим српски језик био у сталном контакту и стално позајмљивао све нове и нове речи, па је о њему остала иронична примедба: [...] Око тога има много запрдица као око Турскога. Грчки је звучао више необично него одбојно, па је прихватан у играма речи и сл.: [...] Пси кси, кси пси, сви сте пси; [...] Одсрбос погркос, одгркос, посрбос. Немачки је нашем човеку звучао више као бесмислена игра него као језик: [...] Олес ајнс, као Шваби тралала; [...] Као Шваба тралала!

${ }^{7}$ О критеријумима за формирање садржаја речника страних речи опште намене в. Клајн/ Шипка 2006: 14-19.

${ }^{8}$ Примере одредница и дефиниција у раду ћемо давати у оној морфолошко-синтаксичкој и правописној форми у којој су забележене у Грчићевом речнику. 
д) богат регистар топонима (Анди, Сцила, Полинезија, Сахара, Стамбол, Боспор итд.);

ђ) називе различитих грађевина и институција (Notre Dame, Лувp, Copбона, сикстинска капела, бастиља итд.);

е) разноврсне дискурзивне формуле заступљене у страним језицима (теремтете! 'од прилике као наше: сто му мука'; дебонкер 'вољно, од свег срца'; salve! 'здраво! добро дошао!'; o sanca simplicitas! 'та ужасна ли незнања!'; à vous 'у ваше здравље'; е бјен (eh bien!) 'е па добро!'; евива (evviva) 'живео! живела!' итд.).

\section{3. Пратећи делови речника: попис скраћеница и списак извора}

2.3.1. У Речнику страних речи Јована Грчића из 1904. године не постоји предговор нити какав уводни текст, у којима се по правилу обзнањују основни циљеви речника, његово место у сопственом лексикографском окружењу, круг корисника којима се обраћа, информације о томе како је речник организован и како се у њему може наћи оно што се тражи (исп. Шипка 2006: 165). ${ }^{9}$ Од пратећих делова анализирани речник садржи попис скраћеница и списак извора.

Попис скраћеница, дат на првој страни речника, обухвата 100 скраћеничких ознака за различите типове етикетирања обухваћене лексичке грађе. Најбројнији су квалификатори којима се упућује на терминолошке области у оквиру којих функционишу одређене језичке јединице страног порекла. Попис

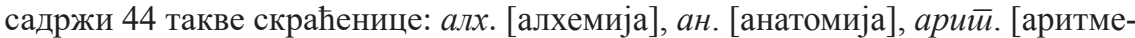

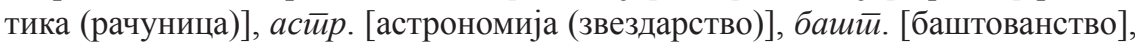
бес. [беседништво], грам. [граматика], мат. [математика], муз. [музика], ков. [ковничарство], щум. [шумарство] итд.

Скраћеница за означавање језика из којег реч потиче или из којег је преузета има укупно 35: ap. [арапски], рус. [руски], лай. [латински], гр. [грчки], шиал. [талијански], $\phi$. [француски], е. [енглески], йур. [турски $]^{10}$ итд.

${ }^{9}$ Издање из 1922. године, које смо такође прегледали, поседује предговор.

${ }^{10}$ Иако је у Грчићевом речнику забележен значајан број турцизама (нпр. само под словом $а$ налазимо одреднице агач, акшам, алат, амал, амед, амиир, аферим, ач, аиамија, аиија, аиуван, аша, ашик, ашлук и др.), прегледањем речника увиђа се да одређени турцизми нису регистровани, као што су нпр. дућан/дућаниија, кујуниија, нахија, пениер, чобанин, за које иначе постоје домаће речи (трговина/трговаи, златар, округ, прозор, пастир). Занимљиво је да многе турцизме Грчић није унео у свој речник иако су они забележени у Вуковом Српском рјечнику, који је, према подацима из списка „извора и помоћница”, Грчић користио као један од извора при ексцерпцији лексике страног порекла. У првом издању Вуковог Српског рјечника (1818) готово једну десетину целокупног лексичког фонда (око 2.500 лексема) чине оријентализми, док их је у другом издању (1852) чак 3.500 (Милановић 2013: 225). За разматрање удела турцизама у речнику страних речи из овог периода значајна је констатација П. Радића да је крајем 19. века, 
У попису се налази и 21 техничка скраћеница за појмове који функционишу као елементи метајезика речничке дефиниције или различитих напомена које претходе дефиницији: гл. [гледај], изг. [изговори], $u$ дp. [и други], $u$. $m$. [исто тако], u. т. д. [и тако даље], нар. [нарочито], об. [обично], озн. [ознака], o. $u$. [од искона], $\mu . n p$. [на пример], $m . j$. [то јест] итд. Попис садржи и скраћеницу посл. [пословица], коју је Грчић користио при обради пословичких структура, углавном преузиманих из класичних језика (грчког и латинског).

2.3.2. На последњој страни речника дат је списак извора из којих је ексцерпирана лексичка грађа. Међу „изворима и помоћницама овом речнику" налази се 13 библиографских јединица. У питању су речници за следеће стране језике: немачки, француски, енглески, италијански, грчки и латински, потом један речник музичких термина, Вуков Српски рјечник (сва три издања) и речник-претходник - Речник страних речи, које се употребљују у нас у говору, у новинама, повременим списима и у књигама, објашњен онима, који те речи не разуму (панчевачко издање из 1882. и допуњено, новосадско издање из 1898). Као што се из овог списка види, од стручних речника (којих треба да буде у великом броју при формирању извора за један речник страних речи) заступљен је само речник музичких термина. ${ }^{11}$

\section{3. МИКРОСТРУКТУРА РЕЧНИКА СТРАНИХ РЕЧИ}

3.0. Питања везана за микроструктуру речника тичу се модела структуирања речничког чланка и распореда релевантних података (исп. Шипка 2006, Хартман 2005: 196). Као један од кључних појмова при опису методологије састављања речничког чланка јавља се појам лексикографског метајезика, тј. језика којим се врши лексикографски опис лексичког материјала. ${ }^{22}$ У домен анализе метајезика условно се сврставају и речнички квалификатори, који имају функцију својеврсне допуне значењу, прецизније - функцију упућивања на „лингвистичке концепте, који су производ стилистичких, семантичких, прагматичких, лексичко-адаптационих, терминолошких и других домена категоризације лексичког система" (Ивановић 2014: 205-206).

У наставку рада ћемо на репрезентативним примерима представити метајезик J. Грчића, пратећи све елементе из структуре речничког чланка:

такозвана филолошка школа, која је фаворизовала пуристички приступ, добила превагу међу српским научницима. Између осталог, наводи даље аутор, представници овог приступа настојали су да многе стране речи - а посебно турске лексичке позајмице - замене српским речима (Радић 2015: 140).

${ }^{11}$ Управо је одсуство бројних јединица из различитих терминолошких области констатовао и В. Ћисаловић (1905: 97) у приказу Грчићевог речника.

${ }^{12}$ в. Ивановић 2014: 196-231. 
квалификаторе, дефиницију, као и све друге релевантне информације дате у чланку којима се регулишу правила употребе стране лексичке грађе.

\section{1. Речнички квалификатори}

3.1.1. За установљење статуса језичких јединица у лексичком систему и правила њихове употребе у писању и говору у дескриптивној, а и у лексикографији уопште, у оквиру одређених лексикографских поступака употребљавају се квалификатори или маркери, што спада у домен лексичког нормирања (Ристић 2016: 113). Грчићев модел обележавања релевантних појава у корпусу стране лексике подразумева употребу граматичких (бележење рода и броја код именица), етимолошких, као и квалификатора за терминолошку детерминацију. Осим ових, Грчић користи и одређене квалификаторе који би се условно могли сврстати у нормативистичке: нпр. квалификатор б. [боље] или изг. [изговори], којима се указује на ортоепску страну одређене стране лексичке грађе: ${ }^{13}$

acti labores jucundi (изг. акти лаборес јукунди) 'кад човек сврши посао, слатко му падне одмор'.

Изговорна страна стране лексике понекад је детерминисана различитим конструкцијама датим у загради, испред дефиниције:

бранша (branche) (у нас кажу бранжа) 'грана н. пр. ког племена, отуд одељење науке (струка), трговине и. т. д.';

комодан (у нас кажу комотан, commode) 'удобан, лагодан';

nастета (у нас увек паштета) 'тестеница, тесто с месом';

лимонада (limonade, у нас мал не увек лимунада) 'вода са шећером и лимуновим соком'.

Међу специфичне елементе метајезика Ј. Грчића убраја се и скраћеница ynp. [управо], која се ставља испред буквалног превода стране језичке јединице:

штих 'упр. убод: у картама, кад ко јачом картом убије';

адвокат (лат. advocatus, упр. дозвани, у помоћ звани) 'заступник, бранилац на суду'; non volat in buccas tuas assa columba 'упр. не лети у твоје образе печен голуб; не ће ти улетети печене шеве у уста'.

За означавање фигуративних значења у речнику коришћен је квалификатор фиг., који спада у метајезичку ознаку из семантичког домена (Ивановић 2014: 213): $:^{14}$

шахмат 'кад се краљ у шаху не може више маћи; фиг. уморан, сустао';

магнет 'гвожђе које привлачи; фиг. ствар, која има неодољиву привлачну снагу';

калибер 'у опште одређена мера; нар. унутрашња ширина цеви, топа, прангије,

ушће у њих; величина и тежина танета; фиг. каквоћа, врста, вредност, багра, пасмина';

маска 'личина, образина; фиг. излика, изговор'.

${ }^{13}$ Сва подвлачења у раду дело су аутора рада.

${ }^{14}$ Ипак, срећу се и одреднице код којих фигуративно значење није евидентирано овим квалификатором, као нпр.: Ђубре: гној; којекаква особа. 
Такође, у речнику се среће и маркер за временску квалификацију грађе: o. $u$. [од искона], чији је пандан у савременој лексикографској пракси квалификатор засй. [застарело]:

гимназија '‥ и. јавно место, где се вежбало тело у старих јелина, сад средња школа'; кратер 'о. и. посуд, у којем се држало вино с водом; левкаст отвор у вулкана'.

У анализираном речнику не налазимо ниједан квалификатор за означавање прагматичко-стилске вредности лексема (нпр. погрд. [погрдно], ир. [иронично], фам. [фамилијарно], вулг. [вулгарно] итд.). ${ }^{15}$ Међутим, иако не експлицитно помоћу квалификатора, Грчић је понегде указивао и на стилске вредности лексема различитим конструкцијама при семантичкој дескрипцији. На пример, на иронични контекст употребе одреднице шпекулант указао је конструкцијом „у иронији” (шпекулант 'прометник, предузетник; у иронији: мудрица'). Хипокористичну компоненту лексеме цанум истакао је конструкцијом „реч одмила” (цанум 'реч од мила, као: срце моје!'). На остваривање лексеме компилатор као експресива са погрдним значењем аутор је указао одредбом „презорно”: компилатор 'састављач, сакупљач; презорно: књижевни крпа, књижевни „крадец”. За својеврсну квалификацију на основу социјалних параметара Грчић је употребио конструкцију „у ђачком језику”: мензура 'мера; у ђачком језику: уговорен двобој, у којем не сме доћи до опасних позледа̂'.

\section{2. Дефиниције}

3.2.0. Лексикографска дефиниција представља идентификацију семантичког садржаја реализоване лексеме (Гортан Премк 2013: 31). Анализом модела интерпретације семантичког садржаја одредничких јединица у Речнику страних речи Ј. Грчића уочавају се различити типови лексикографских дефиниција, који су у великој мери условљени типом лексичке грађе која се дефинише. ${ }^{16}$

3.2.1. Први лексикографски модел подразумева експликацију семантике стране речи помоћу једног синонима или пак синонимског низа, најчешће домаћег порекла:

деликт 'преступ, злочин';

дервиш 'инок, калуђер, пустињак';

15 „Објективно представљање и прецизно маркирање функционално-стилске употребе стране лексике имаће и нормативни значај” (Ристић 1994: 304).

${ }^{16}$ Анализирајући речи страног порекла у шестотомном Речнику $M C$, Вера Васић (1996: 92) констатује два начина дефинисања овог типа лексике: енциклопедијски или појмовни и лексички, семантички. У првом случају одређује се заправо денотат, од чијих особина зависи колико ће дефиниција бити опширна и исцрпна. Лексичке дефиниције се пак, истиче даље ауторка, врло често своде на навођење синонима, обично оних контекстуално необележених или макар необележених у односу на реч коју објашњавају, те је стога значење синонима често шире од значења одреднице. 


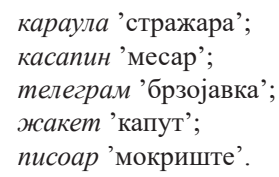

3.2.2. Други модел лексикографског представљања семантичког садржаја страних речи подразумева употребу описних дефиниција, често врло сликовитих: ${ }^{17}$

шапка 'капа горе на четири ћошка';

алиби 'другде. пр.: оптуженик се може позвати на свој alibi, т. ј. може доказати да је био на другом месту, кад се злочин десио';

дилетант 'ко ужива у којој науци или уметности, али не ће у њој да догура далеко, него му је главни позив на другом пољу';

бенђелук 'трава, што се меће у вино или у ракију, да се човек опије и да заспи као мртав';

вулкан 'брег који бљује ватру'.

У оквиру овог модела уочава се и специфичан начин семантичке идентификације речи који подразумева да се прво наводи шире (општије) значење, па се онда ознаком нар. [нарочито] експлицира конкретнији семантички садржај, нпр:

дијета 'уредан живот нар. у јелу и пићу';

тен 'боја, нар. лицу или кожи у опште';

доцент 'предавач (нар. у свенаучишту)';

manem 'простирач на зиду, нар. од бојадисане тканине';

доза 'оброк, нар. кад је реч о лековима';

тропа 'кад ко пропадне, нар. у картама';

компромис 'погодба, којом се реши спор, нар. кад попусти што и једна и друга странка';

гинекологија 'познавање женске природе, нар. у медицинском погледу'.

Нарочито су индикативне парафразе значења одређених медицинских термина, чије је дефиниције аутор конструисао преко сликовитих описа начина употребе тих појмова или ситуација/стања на која они реферишу:

енуреза 'кад ко не може мокраћу да задржи';

акатапоза 'кад болесник не може да пије ни у опште да гута';

анервија 'кад попусте живци';

полуција 'кад ноћу у сну истече семе';

катетер 'пробушена цев, која се тури у цевасти који канал човечјег тела, н. пр. кроз нос у евстајихеву цев, да се удува ваздух, нар. пак у мочницу, да изађе мокраћа'.

Метајезик наведених речничких дефиниција одликује се изразитом живописношћу и ширином експланације карактеристичне за разговорни језик. Код многих дефиниција уочљива је намера аутора речника да што верније дочара контекст у којем се одређена језичка јединица може реализовати, па

${ }^{17}$ Како наглашава Е. Фекете (2002: 84), „описна дефиниција, наиме, даје веће, исцрпне могућности да се појам лексикографски коректно обради”. 
чак у сврху разумљивости значења наводи и врло необичне напомене, као нпр. код одреднице фет.

pem $($ од нем. fett = мастан) 'широка и дебела слова (као ова у овој књизи, којима су штампане стране речи)'.

Јован Грчић понекад при формулисању дефиниције узима у обзир различите особине појма у оквиру искуства говорника, без ограничавања на „нужне и довољне" елементе, што је задатак савремене дескриптивне лексикографије. Наративни карактер који одликује поједине дефиниције из Грчићевог језика приближава, у извесној мери, овај тип дефиниција ономе што се у лублинској етнолингвистичкој школи подводи под појам когнитивне дефиниције. ${ }^{18}$ Тако, нпр. при дефинисању лексеме цамбас, аутор дефиницију не заснива само на типичној компоненти 'познавалац коња', ${ }^{19}$ већ наводи и додатну особину 'који ужива у лепим коњима':

цамбас 'ко познаје коње и ужива у лепим коњима'.

3.2.3. Трећи модел презентације семантичког садржаја лексике страног порекла подразумева употребу тзв. упућивачких дефиниција. Као елеменат метајезика упућивачких дефиниција јавља се ознака гл. [гледај]:

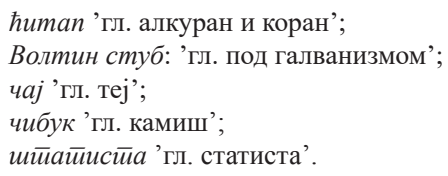

3.2.4. Четврти модел подразумева употребу дефиниција енциклопедијског карактера. Наиме, описи семантичког садржаја многих појмова - по својој опширности и заснованости на екстралингвистичким детаљима - имају карактер енциклопедијских уноса. Енциклопедијску ширину експланације запажамо нарочито код обраде антропонима из области историје, митологије, религије итд., али и код многих других појмова (бомба, бонбон, блуза, темперамент), нпр.:

бомба 'ливена гвоздена шупља кугла, која се из топова у облику лука избацује, да запали зграде, да разори утврђења, да поквари топове или да спречи ма какав посао у рату, разликује се од гранате само својом величином';

Грчићев Речник страних речи близак је енциклопедији и по етимолошким тумачењима настанка одређеног значења, којима се дају информације о историјским или друштвено-политичким околностима у којима су та значења образована или пак информације о пореклу назива одређеног појма:

${ }^{18} \mathrm{O}$ садржају лексикографске дефиниције која је заснована на „принципу логичког и дескриптивног редукционизма”, односно ограниченог избора компонената на „нужне и довољне”, којима се представља само „основни садржај значења” в. Бартмињски 2011: 95-96.

${ }^{19}$ Уп. дефиницију ове лексеме у РМС: цамбас 'човек који се разуме у коње, познавалац коња'. 
карантена 'оних четрдесет дана, што човек проведе под назором на граници, када дође из земље, у којој влада куга';

карневал '(од тал. carne vale = месо, остај с Богом!): упр. време од Богојављења до Пепељаве Среде, за које се од вајкада нар. у Италији весељем и забавама гледало у напред да отштети за часни пост; месојеђе';

пропаганда '(упр. congregatio de propaganda fide): од папе Гргура XV. (од 1621. - 1623) године 1622. уведен стоженички одбор, да шири римокатоличку веру; у опште: задруга или заједница, која тежи да прошири какву науку и да јој стече присталица';

кандидат '(упр. у бело одевен, јер се у старом Риму бело одевали они, који су тражили које звање) ко се иште за што а и који је рад што да постане па је већ на скоку да то добије, н. пр: cand. med: ко је на скоку да постане лечник';

3.2.5. Пети модел у опису значења стране лексичке грађе тиче се дефинисања вишечланих лексичких јединица - израза, пословица, сентенци страног порекла и сл. Овакве језичке јединице су по правилу навођене у изворном облику, а у функцији њихове дефиниције јављају се:

а) значењски еквивалентни изрази истог лексичко-семантичког састава (дословно преведене лексичке компоненте):

a verbis ad verbera: лат. 'с речи на батине', ${ }^{20}$

de mortius nil nisi bene, лат.: 'о мртвима само добро';

divide et impera, лат.: 'растави па владај!';

a capite ad calcem 'од главе до пете';

manus manum lavat 'рука руку мије';

mieux tard que jamais 'боље икад него никад'.

б) значењски еквивалентни изрази различитог лексичко-семантичког састава:

a bove majori discit arare minor (упр.: од старијег вола учи млађи орати) ${ }^{21}$ 'куд ће ивер од кладе';

ab ovo (упр. од јајета) 'од искона'.

в) конструкције које значење израза преносе описно будући да у српском језику не постоји адекватан преводни еквивалент:

medium tenuere beat 'најсрећнији су они, који нису ни сувише горе ни сувише доле'; acti labores jucundi лат. посл. 'кад човек сврши посао, слатко му падне одмор'; per aspera ad astra (упр. преко тешкоћâ до звезда̂) 'ваља свладати највеће сметње па да човек дође до славе',22

per angusta ad augusta (упр. теснацем до врхунца) 'муком може човек постићи све'.

${ }^{20}$ Као фреквентнији еквивалент, у српском језику функционише израз: Ко неће милом, хоће силом.

${ }^{21}$ Ознаком упр. [управо] уводи се буквалан превод израза.

${ }^{22}$ Ова латинска изрека дефинисана је описно, мада у српском језику постоји преводни еквивалент: преко трња до звезда. 


\section{5. ЗАКљУЧНА РАЗМАТРАЬА}

5.1. Резултати лексикографске анализе Речника страних речи Јована Грчића из 1904. године показују нам да речник, иако има кључне елементе који га чине репрезентативним лексикографским делом чији је циљ презентовање лексике страног порекла, ипак има одређене пропусте и недоследности који се могу, у крајњем случају, приписати и томе да је настао у време формирања методолошких поступака у обради лексике страног порекла у српској лексикографији, када још увек нису постојали јасни лексикографски критеријуми, првенствено везани за селекцију лексичког материјала. Речник, наиме, обухвата изузетно широку грађу (као што смо видели, осим терминолошке лексике и лексике из општег лексичког фонда, ту су и страни изрази, пословице, афоризми, сентенце, цитати, скраћенице, богат ономастикон и сл.), највероватније некритички преузиману из речника грчког, латинског и других страних језика. Преоптерећеност речника непотребним речима, које су, без упоришта у стварној језичкој пракси, аутоматски преписиване из страних речника, одлика је методолошког поступка у изради речника страних речи у првој половини 20. века, што директно има реперкусије на практичност и употребну функцију речника. ${ }^{23}$

5.2. Систематизовани резултати анализе макро и микро структуре Речника страних речи Ј. Грчића показују, наравно условно, будући да је презентовано само једно лексикографско остварење, принципе лексикографске дескрипције на самом почетку 20. века. Речнику недостаје предговор у коме би се објаснили његова методологија, намена и циљеви; одреднице нису акцентоване, а грађа је организована по семантичко-деривационом моделу. Лексеме су квалификоване, недоследно, са аспекта граматичких особина, порекла, припадности одређеној теминологији. Стилски квалификатори нису присутни, али се понекад у самој дефиницији срећу различите напомене о употребно-стилској вредности лексема. Нарочита специфичност огледа се у начинима семантизације јединица страног порекла. Наиме, речничке дефиниције карактерише својствен метајезик и, у зависности од типа одреднице, варирају од синонимских до врло широких дескриптивних дефиниција енциклопедијског карактера. Одликује их ширина експланације, нарочити коментари, сликовита поређења, као и честа прожетост елементима разговорног стила.

5.3. Спроведена анализа показује да грађа која је регистрована у Речнику страних речи Ј. Грчића није селектована само са циљем да одговори на комуникативне потребе говорника српског језика, већ и да презентује различите културно-цивилизацијске садржаје других народа. Многе одреднице у

${ }^{23}$ Уп. и констатацију С. Бабића да Клаићев Рјечник страних речи „,zapravo i nije rječnik stranih riječi, već i rječnik stranih jezika, leksikon izreka, sentencija i poslovica na stranim jezicima, on je često leksikon i enciklopedija” (Бабић 1978/1979: 23). 
овом речнику припадају специјализованим речницима, енциклопедијама или лексиконима. Издвојени типови лексичке грађе показују да садржај Грчићевог речника није у потпуном сагласју са формулацијом из наслова да су у питању стране речи које се јављају у нас, будући да регистрована грађа у великој мери не представља појмове који су у стварној језичкој употреби, па чак нуди и више од оног што одговара тадашњим потребама опште културе. Дело оваквог садржаја могло је, међутим, користити у највећој мери едукованим слојевима грађанског друштва заинтересованог за стране језике и упознавање културног идентитета различитих нација.

С обзиром на чињеницу да Речник страних речи Ј. Грчића представља мешавину речника страних речи општег типа, специјализованих речника (нарочито ускотерминолошких), речника страних језика (будући да доноси грађу из различитих страних језика за коју нема потврда да се употребљавала у српском језику) и енциклопедијских дела - можемо констатовати да речник припада жанру који се у литератури назива „хибридним речником” (Хартман 2005).

\section{ИЗВОРИ}

Грчић 1904: Ј. Грчић, Речник страних речи, које се јављају у нас те их ваља разумети, а понешто их се и клонити, Нови Сад: „Браћа М. Поповић”, 1904.

Грчић 1922: Ј. Грчић, Речник страних речи, узречица и пословища, Панчево: „Напредак”.

Клајн/Шипка 2006: И. Клајн, М. Шипка, Велики речник страних речи и израза, Нови Сад: Прометеј.

PMC: Речник српскохрватскога књижевног језика I-VI (1967-1976), Нови Сад (- Загреб): Матица српска (- Матица хрватска).

РСАНУ: Речник српскохрватског књижевног и народног језика САНУ (1959-), I-XXI том, Београд: Институт за српски језик САНУ.

PCJ: Речник српскога језика, прво издање, Нови Сад: Матица српска, 2007.

\section{ЛИТЕРАТУРА}

Бабић 1978/1979: S. Babić, Klaićev Rječnik stranih rječi, Jezik : časopis za kulturu hrvatskoga književnog jezika, god. XXVI/1, 23-29.

Бартмињски 2011: Ј. Бартмињски, Језик-слика - свет. Етнолингвистичке студије, Београд: SlovoSlavia. 
Гортан Премк 2013: Д. Гортан Премк, О лексикографској дефиницији и систему лексикографских дефиниција у једнојезичном речнику, $y$ : М. Алановић и др. (ур.), Leksika - gramatika-diskurs, zbornik u čast Veri Vasić, Нови Сад: Филозофски факултет Универзитета у Новом Саду, 31-39.

Драгићевић 2018: Р. Драгићевић, Српска лексика у прошлости и данас, Нови Сад: Матица српска.

Ђисаловић 1905: В. Ђисаловић, Оцене (Речник страних речи, које се јављају у нас те их ваља разумети а понешто их се и клонити), Летопис Матище српске, бр. 23, Нови Сад, 95-101.

Ивановић 2014: Н. Ивановић, Лексикографски метајезик у речнику САНУ, y: Р. Драгићевић (ур.), Савремена српска лексикографија у теорији и пракси, колективна монографија, Београд: Филолошки факултет, 195-231.

Ивановић 2017: Н. Ивановић, Траговима српске лексикографске културе (анализа једног рукописног речника из прве половине XIX века), Кьижевност и језик, LXIV/1-2, 77-89.

Јовановић 2006: Ј. Јовановић, Къига српских народних пословииа I, II, Београд: Научно друштво за неговање и проучавање српског језика.

Клајн/Шипка 2006: И. Клајн, М. Шипка, Велики речник страних речи и израза, Нови Сад: Прометеј.

Магомедгажиева 2010: Патимат Набижуевна Магомедгаджиева, Историческая эволюция типов словарей иностранных слов. Известия ВГПУ, 2010, № 5. https://cyberleninka.ru/article/n/istoricheskayaevolyutsiya-tipov-slovarey-inostrannyh-slov. Приступљено 1. 9. 2020 .

Милановић 2013: А. Милановић, Језик весма полезан, Београд: Друштво за српски језик и књижевност Србије.

Оташевић 2018: Ђ. Оташевић, Речници страних речи, $y:$ М. Тешић и др. (ур.), Српска лексикографија од Вука до данас - каталог изложбе, Београд: САНУ : Савез славистичких друштава Србије, 293-303.

Павловић 1928: М. Павловић, Речници страних речи у српском књижевном језику, Јужнословенски филолог, VII, 217-230.

Радић 2015: P. Radić, On the Oriental Lexicon in the Serbian Language, $u$ : Lj. Popović, M. Nomachi (ed.), The Serbian Language as Viewed by the East and the West: Synchrony, Diachrony, and Typology, Sapporo: Hokkaido University, 133-149. 
Радовић Тешић 2009: М. Радовић-Тешић, С речима и речником, Београд: Учитељски факултет Универзитета у Београду.

Ристић 1994: С. Ристић, Стране речи у описним речницима, Наш језик, XXIX/5, 301-305.

Ристић 2016: С. Ристић, Граматички и когнитивни аспекти лексичког значења, Београд: Институт за српски језик САНУ.

Спасић 1996: Lj. Spasić, Rečnici stranih reči, y: J. Планкаш (ур.), О лексичким позајмљеницама, Суботица-Београд : Градска библиотека Суботица - Институт за српски језик САНУ, 97-104.

Хартман 2005: R. R. K. Hartmann, Pure or hybrid? The development of mixed dictionary genres, Facta Universitatis, Series: Linguistics and Literature, Vol. 3, № 2, 193-208.

Фекете 2002: Е. Фекете, Употребна вредност лексема и лексикографска дефиниција, Дескриптивна лексикографија стандардног језика и њене теоријске основе, Београд - Нови Сад: Српска академија наука и уметности, Институт за српски језик САНУ - Матица српска, 83-88.

Шипка 2006: D. Šipka, Osnovi leksikologije i srodnih disciplina, Novi Sad: Matica srpska.

\section{A LEXICOGRAPHIC ANALYSIS OF THE THE DICTIONARY OF FOREIGN WORDS OCCURRING IN OUR LANGUAGE, SO \\ THEY SHOULD BE UNDERSTOOD, AND SOMEWHAT EVEN AVOIDED WRITTEN BY JOVAN GRČIĆ IN 1904}

\section{Summary}

Our paper deals with an analysis of the Dictionary of foreign words occurring in our language, so they should be understood, and somewhat even avoided, written by Jovan Grčić in 1904, from a lexicographic point of view, meaning that the main focus of the paper is understanding the concept of the Dictionary, its macro- and micro-structure. This paper aims to use the example of one of the first general dictionaries of foreign words in Serbian to establish the methodological procedures for foreign word processing typical of the Serbian lexicography from the beginning of the 20th century.

Key words: Serbian language, Dictionary of foreign words, Jovan Grčić, lexicography, dictionary macro-structure, dictionary micro-structure. 